\title{
Sistem Informasi Booking Perumahan Berbasis Android pada PT. Bangun Cakra Mandiri Developer
}

\author{
Rosy Riza Tiara ${ }^{1)}$, Suzan Agustri $^{2)}$ \\ ${ }^{1), 2)}$ Program Studi Sistem Informasi, Universitas Indo Global Mandiri \\ Jl. Jend. Sudirman No. 629 KM.4 Palembang 30129 \\ Email : orizatiaraa@gmail.com ${ }^{1)}$, zuzanoid@uigm.ac.id ${ }^{2)}$
}

\begin{abstract}
PT. Bangun Cakra Mandiri Developer is one of leading companies which engaged in residential marketing. The marketing team in PT. Bangun Cakra Mandiri Developer still using conventional methods to promote their home or by spreading brochure. Some of the weakness of that method to sale a their house, first the customer should come to the office to booking the house. Second, the customer don't know the exact location of that housing. The last, there is not information about the house that already booked by other customers. From the above problems, the researcher designed an information system for booking an Android-based housing that is accompanied by a location plan and can book a house at the same time to attract customer interest. In this research, it is expected that the new system is more effective and efficient so that it can accelerate the process of collecting data for prospective buyers and sales data at PT. Bangun Cakra Mandiri using Android for one of its application developments using the Waterfall development method. The results of this research is booking Information Systems the residential booking based on android at PT. Bangun Cakra Mandiri Developer which can help consumers and administration to process consumer booking data.
\end{abstract}

Keywords : Booking, Residential, Android, Waterfall, Unified Modeling Language

\begin{abstract}
ABSTRAK
PT. Bangun Cakra Mandiri Developer adalah salah satu perusahaan terkemuka yang bergerak di bidang pemasaran perumahan. Tim pemasaran di PT. Bangun Cakra Mandiri Developer masih menggunakan metode konvensional untuk mempromosikan rumah mereka atau dengan menyebarkan brosur. Beberapa kelemahan dari metode itu untuk menjual rumah mereka, pertama pelanggan harus datang ke kantor untuk memesan rumah. Kedua, pelanggan tidak tahu persis lokasi perumahan itu. Terakhir, tidak ada informasi tentang rumah yang sudah dipesan oleh pelanggan lain. Dari permasalahan diatas, peneliti merancang sebuah sistem informasi pem-booking-an perumahan berbasis android yang di sertai denah lokasi dan dapat melakukan booking rumah sekaligus untuk menarik minat pelanggan. Pada penelitian ini diharapkan sistem yang baru lebih efektif dan efisien sehingga dapat mempercepat proses pengumpulan data bagi calon pembeli dan data penjualan pada PT. Bangun Cakra Mandiri menggunakan Android untuk salah satu pengembangan aplikasinya dengan metode pengembangan Waterfall. Hasil dari penelitian ini adalah Sistem Informasi booking perumahan berbasis android di PT. Bangun Cakra Mandiri Developer yang dapat membantu konsumen dan administrasi untuk proses pengolahan data booking konsumen.
\end{abstract}

Kata kunci : Pemesanan, Perumahan, Android, Waterfall, Unified Modeling Language 


\section{Pendahuluan}

Era globalisasi saat ini banyak sekali kemajuan dan perubahan yang terjadi dalam dunia bisnis modern. Adapun perubahan yang terjadi ditandai dengan pola pikir masyakat yang berkembang, kemajuan teknologi, dan gaya hidup yang tidak lepas dari pengaruh globalisasi. Dengan adanya kemajuan dan perubahan tersebut secara tidak langsung menuntut kita untuk dapat mengimbanginya dalam kehidupan sehari-hari.

Perkembangan teknologi yang sangat pesat mendorong masyarakat menggunakan teknologi untuk dapat berkembang. Saat ini teknologi mobile dan tablet PC (Personal Computer) tidak hanya digunakan sebagai alat komunikasi, tetapi juga digunakan sebagai sarana untuk mempermudah penggunanya dalam kehidupan sehari-hari misalnya untuk medapatkan berbagai informasi. Hal tersebut dapat terjadi karena pada teknologi mobile dan tablet PC (Personal Computer) terdapat fasilitas seperti akses internet, e-mail dan multimedia yang dapat digunakan dimana saja dan kapan saja.

PT. Bangun Cakra Mandiri Developer merupakan perusahaan yang cukup terkemuka bergerak di bidang pemasaran perumahan. Pemasaran perumahan yang di bangun, PT. Bangun Cakra Mandiri Developer masih menggunakan metode konvensional yaitu menyebar brosur, untuk pembookingan rumah para calon konsumen datang ke kantor developer, selain itu calon konsumen belum dapat melihat denah lokasi rumah. Calon Konsumen hanya mengandalkan brosur yang didapa untuk mengetahui blok rumah mana saja yang sudah ter-booking. Permasalahan tersebut, melatarbelakangi peneliti untuk merancang sebuah sistem informasi pem-booking-an perumahan berbasis android yang di sertai denah lokasi dan dapat melakukan booking rumah sekaligus untuk menarik minat pelanggan.

Pemilihan mobile android untuk salah satu pengembangan aplikasi selain lebih mudah dalam pengoperasiannya, juga karena sifat dari mobile yang fleksibel menjadi salah satu alasan peneliti memilih media ini untuk dikembangkan di PT. Bangun Cakra Mandiri Developer, oleh karena itu peneliti menentukan judul penelitian "Sistem Informasi Booking Perumahan Berbasis Android pada PT. Bangun Cakra Mandiri Developer".

\section{A. Sistem Informasi}

Menurut Agus Mulyanto, sistem informasi adalah suatu komponen yang terdiri dari manusia, teknologi informasi, dan prosedur kerja yang memproses, menyimpan, menganalisis, dan menyebarkan informasi untuk mencapai tujuan[1] [8][12][26].

\section{B. Perumahan}

Manurung menjelaskan, rumah adalah tempat tinggal dan tempat berteduh dari panasnya matahari serta dinginnya hujan. Rumah juga sebagai tempat melakukan beragam aktivitas.
Menurut UU No. 4 Tahun 1992 tentang Perumahan dan Permukiman, perumahan berada dan merupakan bagian dari permukiman, perumahan adalah kelompok rumah yang berfungsi sebagai lingkungan tempat tinggal atau lingkungan hunian yang dilengkapi dengan prasarana dan sarana lingkungan (pasal 1 ayat 2).

Permukiman dan pemukiman merupakan dua istilah yang dipakai dalam menyebutkan tempat tinggal atau kediaman seseorang. Penggunaan dua istilah ini jika ditinjau memiliki makna yang berbeda, namun sering dirancukan penggunaanya. "Tempat tinggal atau tempat kediaman secara umum disebut permukiman dan secara khusus disebut bangunan rumah". Wesnawa $[10][25][27]$.

\section{Penjualan}

Menurut Basu Swastha dalam Irwan Sahaja, penjualan adalah suatu proses pertukaran barang atau jasa antara penjual dan pembeli. Jadi dapat disimpulkan bahwa penjualan adalah usaha yang dilakukan manusia untuk menyampaikan barang kebutuhan yang telah dihasilkan kepada mereka yang membutuhkan yang telah ditentukan atas tujuan bersama [22].

\section{Android}

Android adalah sebuah sistem operasi untuk perangkat mobile berbasis linux yang mencakup sistem operasi, middleware dan aplikasi. Android menyediakan platform terbuka bagi para pengembang untuk menciptakan aplikasi mereka [19][21].

\section{E. Mobile Application}

Mobile application adalah sebuah aplikasi yang memungkinkan manusia melakukan mobilitas dengan menggunakan perlengkapan seperti PDA (Personal Digital Assistant ), telepon seluler (handphone). Dengan menggunakan aplikasi mobile, manusia dapat dengan mudah melakukan berbagai macam aktivitas mulai dari hiburan, berjualan, belajar, mengerjakan pekerjaan kantor, browsing, chatting email, dan lain sebagainya [27].

\section{F. Waterfall}

Menurut Youssef Bassil, Model air terjun (waterfall) sering disebut model sekuensial linear (sequential linear) atau alur klasik (classic life). Model air terjun menyediakan pendekatan hidup perangkat lunak secara sekuensial atau terurut dimulai dari analisis, desain,pengkodean, pengujian dan tahap pendukung (support).

Metode Waterfall memiliki alur beberapa tahapan adalah sebagai berikut : 


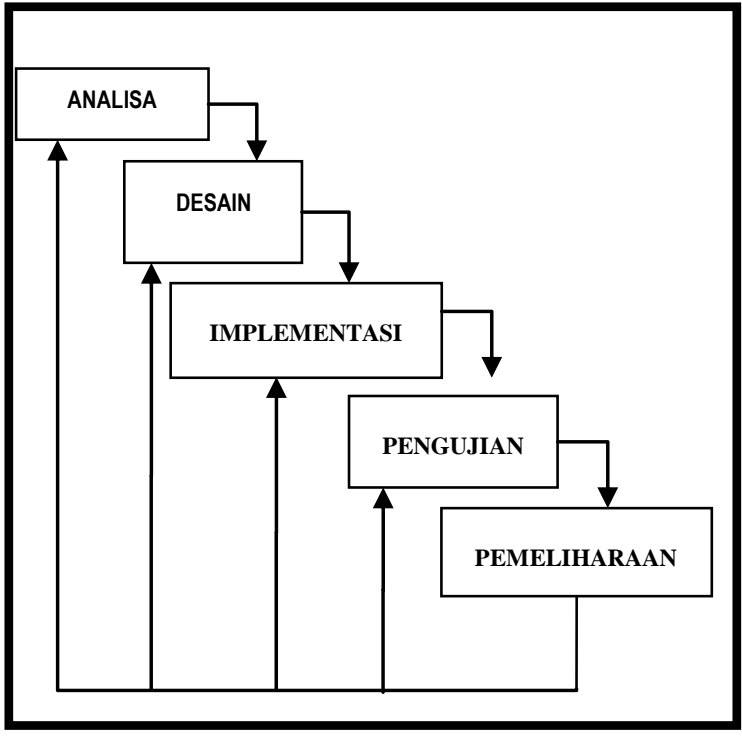

Gambar 1. Waterfall

Model sekuensial linier memiliki beberapa tahapan proses, yaitu :

1. Analisa

Tahap ini sering dikenal sebagai Software Requirements Specification (SRS) sebuah penjelasan lengkap dan komprehensif dari fungsi perangkat lunak untuk dikembangkan. Ini menyangkut sistem dan analisis bisnis untuk mendefinisikan persyaratan fungsional maupun non-fungsional. Biasanya, persyaratan fungsional didefinisikan melalui penggunaan kasus-kasus yang menggambarkan interaksi pengguna dengan perangkat lunak.

2. Desain

Tahap ini adalah proses perencanaan dan pemecahan masalah untuk solusi perangkat lunak. Ini menyangkut pengembang perangkat lunak dan perancang untuk menentukan rencana untuk sebuah solusi yang mencakup desain arsitektur perangkat lunak, skema konseptual database dan desain diagram yang sesuai, konsep desain, desain antarmuka pengguna grafis, dan definisi struktur data.

3. Implementasi

Tahap ini merujuk kepada realisasi kebutuhan sistem dan spesifikasi desain ke dalam eksekusi program yang nyata, database, situs web atau komponen perangkat lunak melalui pemrograman dan

4. Pengujian

Pengujian fokus pada perangkat lunak secara dari segi logic dan fungsional dan memastikan bahwa semua bagian sudah diuji. Hal ini dilakukan untuk meminimalisir kesalahan (error) dan memastikan keluaran yang dihasikan sesuai dengan yang diinginkan.

5. Pemeliharaan

Tahap ini adalah proses memodifikasi perangkat lunak setelah implementasi dan penerapan proses output, memperbaiki kesalahan, dan meningkatkan kinerja dan kualitas pada perangkat lunak. Kegiatan pemeliharaan ini juga termasuk adaptasi perangkat lunak dengan lingkungan, mengakomodasi pengguna baru, dan meningkatkan kehandalan perangkat lunak.[2]

\section{G. $M y S Q L$}

Menurut (Abdul Kadir, 2008), MySQL merupakan perangkat lunak database server yang menggunakan antarmuka bahasa SQL (Structure Query Language).

SQL sendiri merupakan bahasa yang terstruktur yang digunakan untuk interaksi antara pengguna dengan database server dalam hal pengolahan data. Dengan SQL, kita dapat membuat tabel yang nantinya akan diisi dengan data, memanipulasi data (misalnya menambah data, menghapus data dan memperbaharui data), serta membuat suatu perhitungan dengan berdasarkan data yang ditemukan[8][18].

\section{Pembahasan}

\section{A. Use Case Diagram Saat Ini}

Proses berikut ini menjelaskan proses yang terkait dengan aktor dan sistemnya, yang merupakan interaksi antara aktor dan sistem. Interaksi tersebut dapat digambarkan dengan Use Case Diagram untuk Sistem Informasi Pemesanan Perumahan pada PT. Bangun Cakra Mandiri :

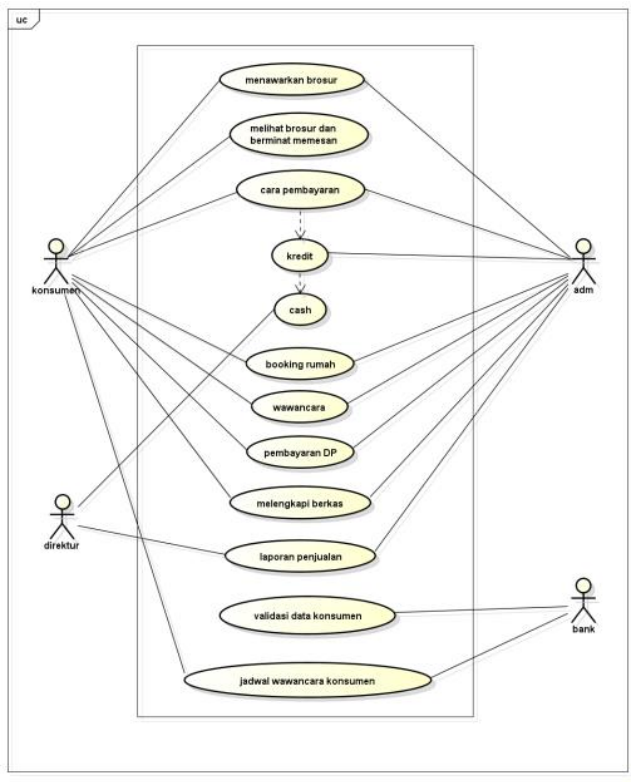

Gambar 2. Use Case Diagram Saat Ini

\section{B. Activity Diagram}

Activity diagram melihat status rumah dan melakukan booking rumah ini menggambarkan konsumen/konsumen dapat melihat status rumah dan melakukan booking apabila status rumah belum di jual[18].

Berikut activity diagram yang di usulkan : 


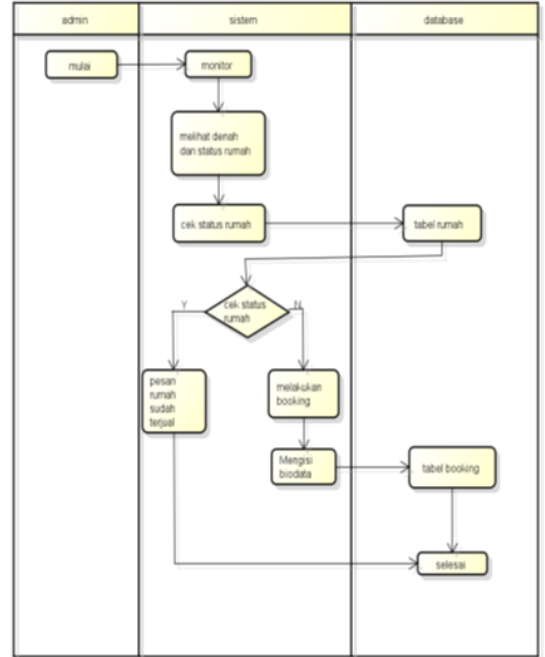

Gambar 3. Activity Diagram Usulan

\section{Sequance Diagram}

Sequence Diagram bawah ini menggambarkan serangkaian interaksi antara aktor konsumen dalam booking rumah yang mereka inginkan[18].

Berikut gambar sequance diagram usulan

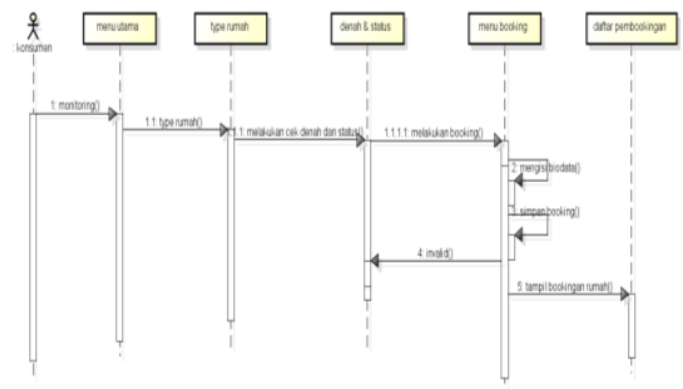

Gambar 4. Sequance Diagram Usulan

\section{Class Diagram}

Diagram kelas atau class diagram menggambarkan struktur sistem dari segi pendefinisian kelas-kelas yang akan dibuat untuk membangun sistem[18].

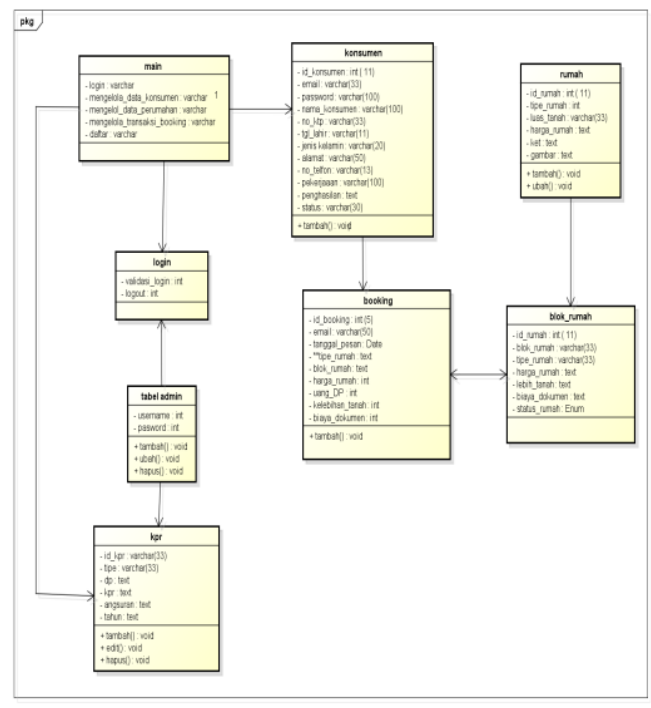

Gambar 5. Class Diagram Usulan
E. Halaman Splash Screen

Tampilan awal pada saat membuka aplikasi Penjualan Perumahan, terdapat informasi berupa foto rumah, lokasi, dan sekilas promisi

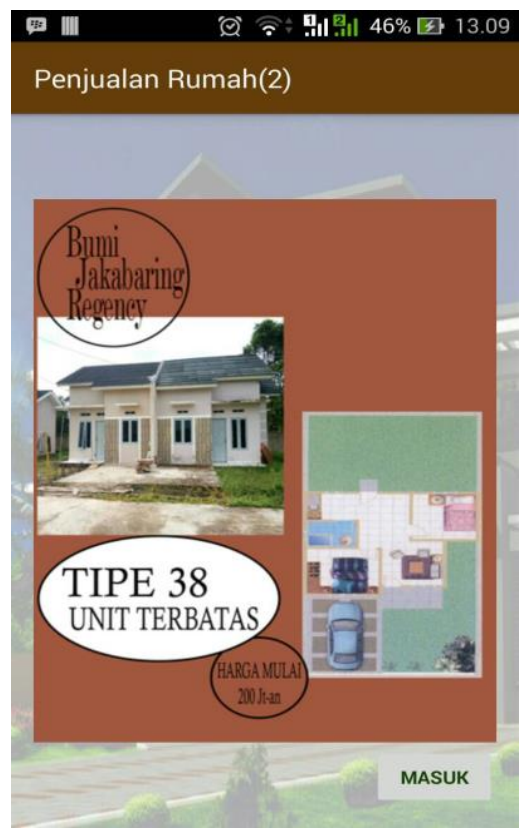

Gambar 6. Tampilan Halaman Splash Screen

Halaman Menu Utama Admin ini akan terbuka jika admin telah mengklik tomol button untuk dapat melakukan ke halaman berikutnya.

\section{F. Halaman Promo}

Halaman Promosi untuk menampilkan Rumah yang di Promosi oleh Pihak Developer

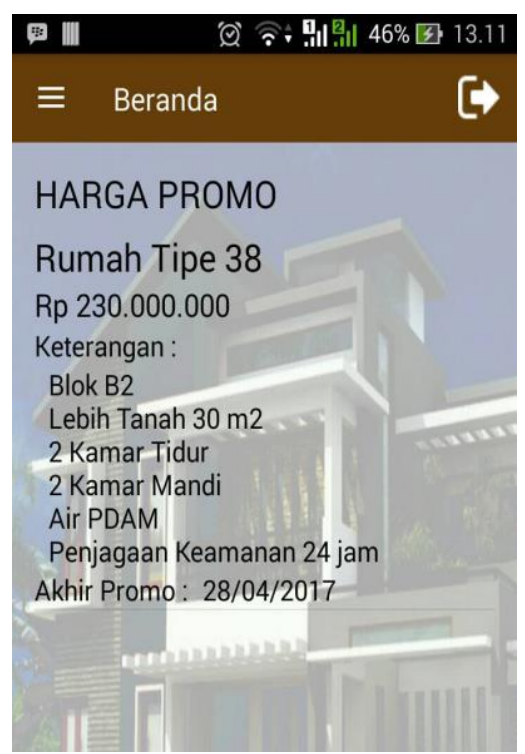

Gambar 7. Tampilan Halaman Promo

\section{G. Halaman Menu Beranda}

Halaman yang menampilkan menu apa saja yang tersedia di android booking perumahan. 


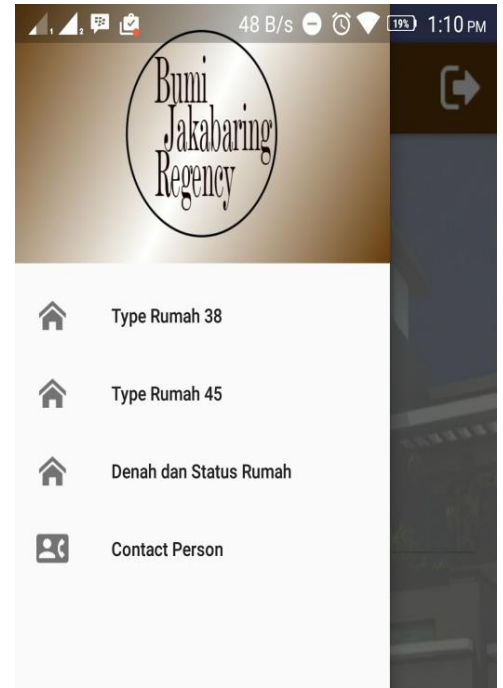

Gambar 8. Tampilan Halaman Menu di Beranda

\section{H. Halaman Tipe Rumah}

Menu Tipe Rumah 38 akan menampilkan halaman untuk melihat Foto Rumah, Denah, Spesifikasi, konsumen dapat melihat dengan menggeser foto kesebelah kiri.

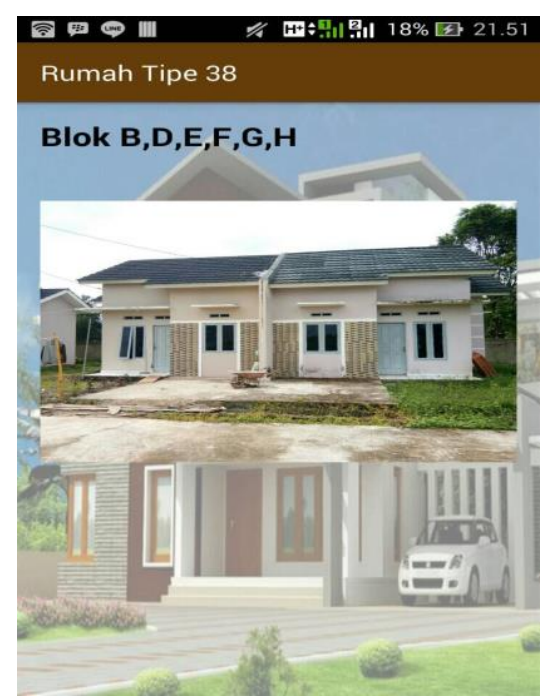

Gambar 9. Tampilan Halaman Tipe Rumah

\section{Halaman Denah \& Status Rumah}

Pada menu denah dan Status Rumah Serta Form Booking adalah halaman yang menyediakan tempat untuk konsumen dapat melihat denah rumah dan juga bisa melihat status rumah apakah blok rumah yang diinginkan masih tersedia atau tidak, jika masih ada konsumen dapat mengklik blok rumah tesebut kemudian mem-booking rumah. Berikut dapat di lihat tahapantahapan untuk mem-booking rumah, dimulai dengan melihat denah rumah:

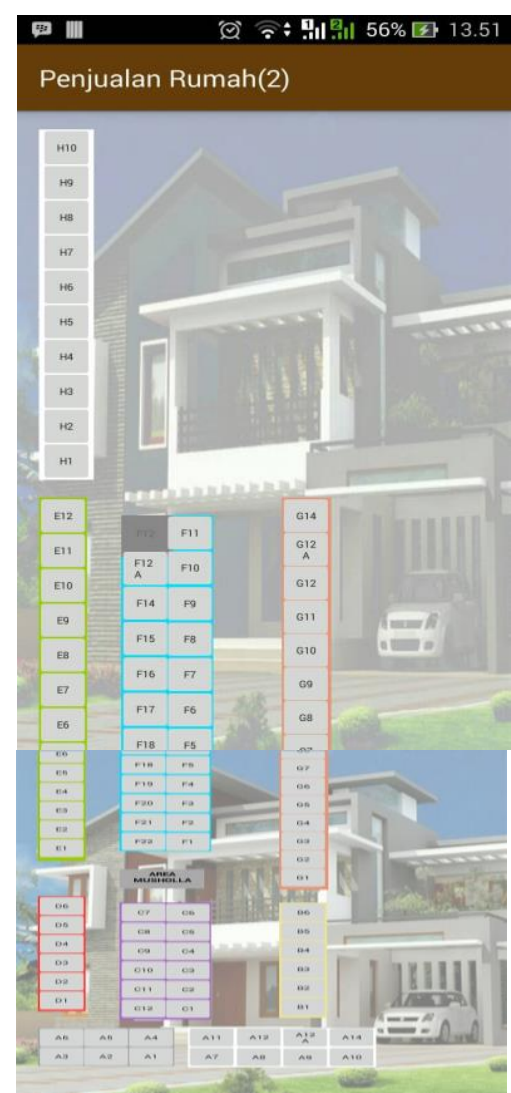

Gambar 10. Tampilan Denah Rumah

\section{H. Tampilan Booking}

Form booking muncul ketika konsumen mengklik salah satu blok yang ada di daftar rumah yang statusnya tersedia. Untuk mem-booking klik button booking setelah itu akan tampil form daftar.

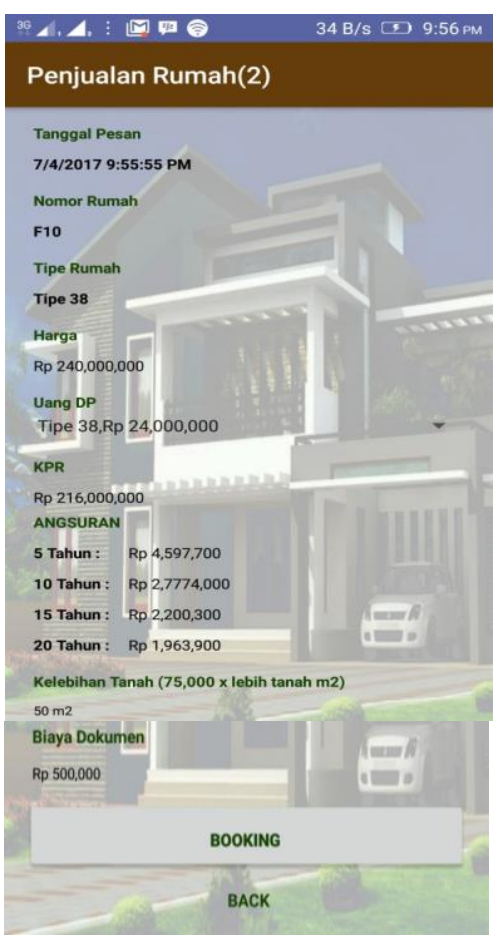

Gambar 11. Tampilan Form Booking 


\section{Tampilan Daftar Biodata Konsumen}

Tampilan Daftar Biodata tampil ketika konsumen mengklik button Booking, maka akan tampil seperti gambar di bawah ini:

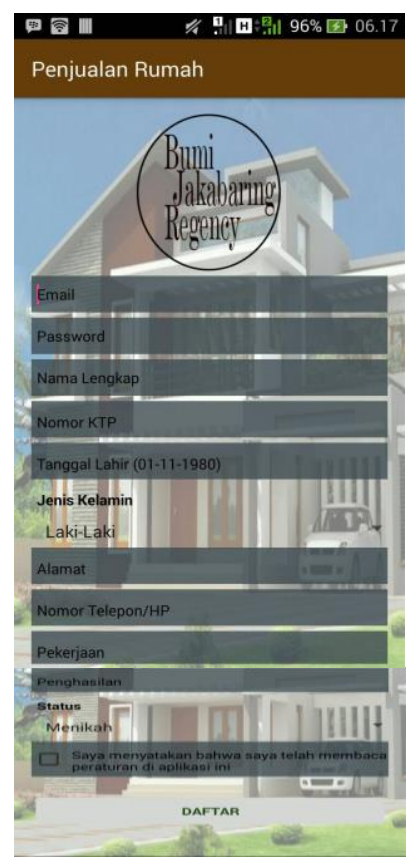

Gambar 12. Tampilan Form Isi Biodata

\section{J. Tampilan Contact Person}

Pada halaman Contact Person ini berisi nomor telepon pihak developer.

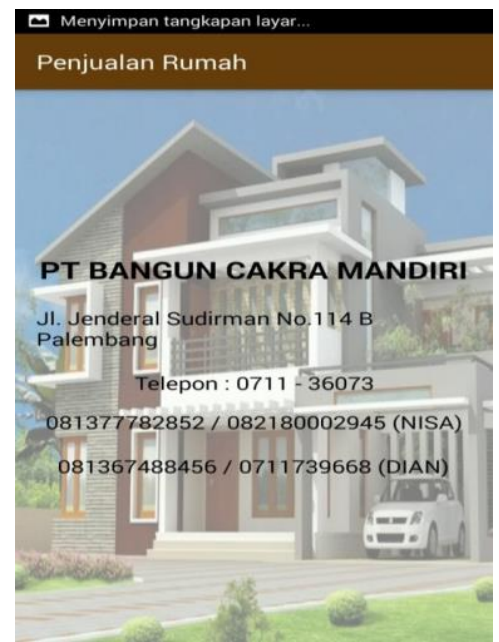

Gambar 13 . Tampilan Contact Person

\section{K. Pengujian}

Proses pengujian dilakukan untuk mengetahui kemungkinan terjadinya kesalahan pada skrip atau form, navigasi ataupun tampilan. Pengujian aplikasi menggunkan Blackbox

\section{Kesimpulan}

Berdasarkan pembahasan dan uraian pada bab sebelumnya mengenai pembuatan Sistem Penjualan
Perumahan Berbasis Android pada PT. Bangun Cakra Mandiri, maka peneliti sebagai berikut :

1. Konsumen dapat melihat denah lokasi rumah sekaligus melakukan booking rumah yang di inginkan tanpa harus datang langsung ke kantor.

2. Aplikasi Booking perumahan ini selain dapat membantu konsumen, juga bisa membantu administrasi untuk proses pengolahan data booking konsumen.

3. Aplikasi ini berjalan pada smartphone yang mendukung platfrom android

\section{Saran}

Berdasarkan kesimpulan peneliti memberikan saran kepada pihak PT. Bangun Cakra Mandiri dalam hal promosi yaitu di antaranya :

1. Mengurangi tingkat pemalsuan data dalam booking perumahan maka disarankan pengembangan sistem keamanan yang dapat melakukan validitas data konsumen yang akan membooking lokasi perumahan.

2. Pengembangan aplikasi ini seharusnya berorientasi pada pengembangan modul penjualan perumahan berbasis android.

\section{Daftar Pustaka}

Agustri, Suzan 2012, "Perencanaan Strategi Sistem Informasi Studi Kasus UIGM, UI"

Bassil, Youssef 2011 , Jurnal "A Simulation Model for the Waterfall Software Development Life Cycle"

Buttle, Francis 2007. Custumer Relationship Management (Manajemen Hubungan Pelanggan), Bayumedia, Jakarta.Sutabri, Tata.2012.Analisis Sistem Informasi. Andi. Yogyakarta.

Hanafie, R 2010, Pengantar Ekonomi Pertanian, Andi Offset, Yogyakarta.

Indrajani 2015, Database Design (Case Study All in One). PT Elex Media Komputindo, Jakarta.

International Jurnal of Engineering \& Technology, ISSN: 2049-3444

Jogiyanto, Hartono 2008, Metodologi Penelitian Sistem Informasi. Andi Offset, Yogyakarta.

Kadir, Abdul 2008, Tuntunan Praktis Belajar Database Menggunakan MySQL, Andi Offset, Yogyakarta.

Kadir, Abdul 2010, Pengenalan Sistem Informasi, Andi Offset, Yogyakarta.

Manurung 2010, Panduan Sukses Menjual Reksadanai, Grasindo, Jakarta.

Moekijat, Prasojo 2011, Pengantar Sistem Informasi Manajemen CV.Remadja Karya, Bandung.

Mulyanto, Agus 2010, Sistem Informasi Konsep dan Aplikasi, Pustaka Pelajar, Yogyakarta.

Nugroho, Adi 2010, Rekayasa Perangkat Lunak Berbasis Objek dengan Metode USDP, Andi Offset, Yogyakarta.

Nugraha Arief dkk 2012, Jurnal, "Aplikasi Perhitungan Sistematis dan Informasi Penjualan Perumahan Berbasis Android pada PT. Pulau Jaya Abadi" Palembang. 
Oktariani 2012, Jurnal "Sistem Informasi Penjualan Perumahan pada PT. Karya Utama Jaya Palembang" Palembang.

Praningrum 2013, Analisis Pengaruh Lingkungan Kerja dan Etos Kerja Terhadap Kinerja Pegawai Dinas Pendidikan Nasional Kota Bengkulu.

Roger, S Pressman 2010, Software Engineering, metode waterfall model.

Rosa, M. Shalahuddin 2013, Rekayasa Perangkat Lunak Terstruktur dan Berorientasi Objek. Informatika, Bandung.

Sadeli, Muhammad 2014, Toko Buku Online dengan Android. Maxikom, Palembang.

Sastradipura, Komaruddin 2003, Manajemen Marketing, Bandung.

Safaat H, Nazruddin 2012, (Edisi Revisi) Pemograman Aplikasi Mobile Smartphone dan Tablet PC Berbasis Android. Informatika. Bandung.

Sahaja, Irwan 2013, Bauran Pemasaran Jasa, diakses 16 Januari 2017 dari http://irwansahaja. blogspot.com/2013/05/bauran-pemasaran-jasa.html

Sutabri, Tata 2005, Sistem Informasi Manajemen, Jakarta.

Sutabri, Tata 2012, Analisis Sistem Informasi, Andi Offset, Yogyakarta.

Wesnawa 2010, Perubahan Lingkungan Permukiman Mikro Daerah Perkotaan, Surakarta.

Yakub 2012, Pengantar Sistem informasi, Graha Ilmu, Yogyakarta.

Yonarisa F, 2012, Mobile Apps, diakses 25 Januari 2017 dari Kampusku Kampus IT: http://blog.akakom.ac.id/faridayonarisa/ 2012/09/07/mobile-apps/ 